\title{
Tip II Diabetes Mellitus Ve Tiroid Hastalarında Gözlenen Deri Bulguları ve Karşılaştırılması
} SKIN FINDINGS AND THEIR COMPARISION IN PATIENTS WITH TYPE II DIABETES MELLITUS AND THYROID DISEASE

\author{
Özlem ÖZBAĞÇIVAN, Sevgi AKARSU, Emel FETİL
}

Dokuz Eylül Üniversitesi Tıp Fakültesi, Dermatoloji Ana Bilim Dalı

\section{ÖZET}

Amaç: Diabetes Mellitus (DM) ve Tiroid Hastalıkları (TH) sık görülen kronik metabolik hastalıklardır. Bu hastalıkların tanısı, seyri ve komplikasyonları ile ilgili yardımcı belirtiler olabileceğini düşündüğümüz dermatolojik bulguları araştırmak amacıyla araştırmamıza Tip II DM veya TH tanısı olan olgular alınmıştır.

Yöntemler: Araştırmaya Tip II DM $(n=100)$ veya TH $(n=100)$ tanısı olan olgular alınarak ayrıntılı bir dermatolojik muayeneden geçirilmiştir. Tüm olguların dosyaları, demografik verileri, hastalığa özgün öyküleri, eşlik eden hastalıkları, medikasyonları ve laboratuar bulguları açısından retrospektif olarak taranmıştır.

Bulgular: DM grubunda en sık gözlenen dermatolojik bulgular fibroma molle (\%51), onikomikoz (\%38) ve hemangioma (\%33); TH grubunda ise tırnak bulguları (\%64), saç dökülmesi (\%45), kserozis (\%37) ve plantar hiperkeratoz (\%37) olarak belirlenmiştir. Onikomikoz ve tinea pedis DM grubunda $(p=0,030, p=0,003)$, tırnak bulguları $(p=0,001)$ ve saç bulguları $(p=0,001)$ ise TH grubunda daha fazla oranda izlenmiştir.

Sonuç: Özellikle ileri yaş grubundaki diyabetli hastalarda önemli morbidite ve mortalite nedeni olan mikotik infeksiyonlar araştırmamızda yüksek oranlarda saptanmıştır. DM hastalarında mikotik infeksiyonlar dermatolojik muayenenin rutin bir parçası olmalıdır. Bunun yanında saç dökülmesi, saç yapısında değişiklikler ve tırnak bulguları ile dermatoloji polikliniklerine başvuran olguların klinik ve laboratuvar incelemeler ile tiroid hastalıkları açısından araştırılması uygun olacaktır.

Anahtar sözcükler: Tip II Diabetes mellitus, tiroid hastalıkları, deri bulguları, dermatolojik bulgular

\section{SUMMARY}

Objective: Diabetes Mellitus (DM) and Thyroid Disease (TD) are common chronic metabolic disorders. Patients with Type II DM or TD were inrolled in our study to determine dermatological findings which may be associated with the diagnosis, prognosis and complications of these diseases.

Methods: Type II DM $(n=100)$ and TD $(n=100)$ patients were enrolled in the study and

Özlem ÖZBAĞÇıvAN

Dokuz Eylül Üniversitesi

Tip Fakültesi

Dermatoloji AD

IZMIR a detailed dermatological examination was done. The files of all patients were retrospectively reviewed in terms of demographic data, disease-specific history, accompanying diseases, medications and laboratory findings.

Results: The most frequently observed dermatological findings were fibroma molle (\%51), onicomycosis (\%38) and hemangioma (\%33) in DM group and nail findings 
(\%64), hair loss (\%45), xerosis (\%37) and plantar hyperkeratosis (\%37) in TD group. While onicomycosis $(p=0,030)$ and tinea pedis $(p=0,003)$ were more frequent in DM group, nail $(p=0,001)$ and hair findings $(p=0,001)$ were more frequent in TD group.

Conclusion: Mycotic infections which cause significant morbidity and mortality especially in older diabetic patients were determined at higher rates in our study. Screening for mycotic infections in patients with DM should be a routine part of the dermatological examination. In addition we assumed that it would be more appropriate to research for thyroid disease in patients presenting with signs and symptoms of hair loss, changes in the structure of hair and nails.

Key words: Type II Diabetes mellitus, thyroid disease, skin findings, dermatological findings

Diabetes Mellitus (DM) ve Tiroid Hastalıkları (TH) endokrinolojik hastalıklar içinde en sık gözlenen, geniş yaş gruplarında ve sosyoekonomik seviyelerdeki bireyleri etkileyen kronik metabolik hastalıklardır. Her iki grup hastalıkta da pek çok deri bulgusu gözlenebilmektedir (1). Deri bulguları genellikle tanı sonrası hastalığın seyri esnasında ortaya çıkmakta iken, bazen de hastalığın ilk bulgusu olmaktadır (2). Bu metabolik hastalıklarda görülen deri bulguları; akut metabolik düzensizlikler veya kronik dejeneratif komplikasyonlar ile ilişkili olabileceği gibi bu hastalarda sıklığı artmış ancak spesifik olmayan bulgular olarak da karşımıza çıkabilmektedir $(3,4)$. Bu hastalıkların tanısı, seyri ve komplikasyonları ile ilgili yardımcı belirtiler olabileceğini düşündügüumüz dermatolojik bulguları araştırmak amacıyla araştırmamıza DM veya TH tanısı almış olan olgular alınmıştır.

\section{GEREÇ VE YÖNTEM}

Bu araştırmaya Dokuz Eylül Üniversitesi Tıp Fakültesi Endokrinoloji Anabilim Dalı'nda Tip II DM veya TH tanıları ile takip edilmekte olan ve Dermatoloji Polikliniği'ne müracaat eden hastalar alınmıştır. Hastaların deri bilimsel muayenesi yapılarak mevcut dermatolojik bulguları kayıt edilmiştir. Araştırma öncesi Dokuz Eylül Üniversitesi Girişimsel Olmayan Klinik Araştırmalar Etik Kurulu'ndan izin alınmış ve araştırmaya dahil edilen tüm hastalara aydınlatılmış onam formları imzalatılmıştır. Arşiv verilerinde tetkik sonuçları bulunmayan, DM veya $\mathrm{TH}$ dışında ek kronik hastalığı olan, hem diyabet hem tiroid hastalığı olan olgular, gebe ve emziren kadınlar ve 18 yaş altındaki olgular araştırmaya dahil edilmemiştir.

Araştırmaya alınan tüm hastaların yaş ve cinsiyet gibi demografik verilerinin yanı sıra kayıtları taranarak DM'li hastaların HbA1c düzeyi, nöropati, retinopati ve nefropati varlığı, TH'li hastaların T3, T4, TSH, ATPO ve ATG düzeylerine ulaşılmıştır. Tüm hastalar saç, saçlı deri, mukozalar ve tırnaklar dahil olmak üzere ayrıntılı bir dermatolojik muayeneden geçirilmiştir. Gerekli görülen olgularda wood 1şığı muayenesinden ve mikolojik direk bak1/kültür yöntemlerinden yararlanılmıştır.

Verilerin istatiksel analizi SPSS 15 programı kullanılarak yapılmıştır. Tanımlayıcı analiz ile sayısal değişkenler ortalama \pm standart sapma olarak, diğer değişkenler ise yüzde sıklıkları olarak elde edilmiştir. Dermatolojik bulgular ile yaş, cinsiyet, HbA1c düzeyi, hastalık süresi, hastalık tipi ve komplikasyonların ilişkisinin değerlendirilmesinde ki-kare, Fisher'in kesin testi ve Pearson korelasyon testleri kullanılmıştır. Elde edilen verilerde $p<0,05$ değerleri istatistiksel olarak anlamlı kabul edilmiştir.

\section{BULGULAR}

Araştırmaya Tip II DM veya TH tanısı olan 100'er hasta alınmıştır. Hastaların demografik özellikleri Tablo I'de özetlenmiştir. DM'li hastaların \%29'unda nöropati, $\% 25$ 'inde retinopati, \%4'ünde ise nefropati komplikasyonu saptanmış olup hastaların \%56'sının Oral Anti Diyabetik (OAD), \%37'sinin insülin, \%6'sının ise OAD + insülin kullanmakta olduğu belirlenmiştir. TH grubundaki hastaların \%35'inde hipotiroidi, \%16'sında hipertiroidi, \%49'unda ise ötiroidik noduler guatr hastalığı saptanmış olup hastaların \%58'inin tiroid replasman tedavisi kullandiğı belirlenmiştir.

DM grubunda en sık gözlenen üç dermatolojik bulgu fibroma molle, onikomikoz ve hemangioma şeklinde; $\mathrm{TH}$ grubunda en sık gözlenen üç dermatolojik bulgu ise tırnak bulgusu, saç dökülmesi, kserozis ve aynı oranda plantar hiperkeratoz şeklinde saptanmıştır. Hastalarda gözlenen dermatolojik bulgular en sıktan en aza doğru Tablo II ve 
III'te özetlenmiştir.

DM grubunda fibroma molle, hemangioma, lentigo solaris ve seboreik keratoz sıklığı TH grubuna oranla daha fazla saptanmış ancak aradaki fark istatistiksel açıdan anlamlı bulunmamıştır. Onikomikoz ve tinea pedis sıklığının DM grubunda TH grubuna oranla istatistiksel olarak anlamlı düzeyde fazla olduğu belirlenmiştir ( $p=0,030$, $p=0,003)$. Onikomikoz sıklığının yaş arttıkça her iki grupta da anlamlı olarak arttığı gözlenmiştir $(p=0,021, p=0,021)$.

TH grubunda tırnak bulgularının DM grubundan daha fazla olduğu belirlenmiştir $(p=0,001)$. En sık görülen tırnak bulguları longitudinal çizgilenmeler ve distal onikoliz olarak saptanmıştır. Bakteriyel enfeksiyonlardan eritrazma ve folikülit DM grubunda daha fazla saptanmış ancak iki grup arasında istatistiksel olarak anlamlı fark belirlenmemiştir.

DM grubunda diyabet süresi 10 yıl ve üzerindeki hastalarda dermopati ve palmar eritem sıklığının arttığı izlenmiştir ( $p=0,031, p=0,007)$. Yine nöropatisi olan hastalarda palmar eritem, rubeozis fasiei, kserozis ve onikomikoz sıklığının da anlamlı derecede artmış olduğu belirlenmiştir ( $p=0,005, p=0,050, p=0,001, p=0,007)$. TH gru- bunda generalize pruritus yakınması hipotiroidisi olan hastalarda daha fazla oranda saptanmış olup bu hastalardaki pruritus yakınmasının kserozis ile ilişkili olduğu düşünülmüştür $(p=0,005)$.

Saç bulguları genel olarak TH grubunda daha fazla gözlenmiştir $(p=0,001)$. Saç yağlanması ve saç dökülmesi hipertiroidi hastalarında $(p=0,002, p=0,008)$; saç kuruluğu ise hipotiroidi hastalarında daha fazla izlenmiştir $(p=0,030)$.

\section{TARTIŞMA}

Diyabet ve tiroid hastalıkları endokrin sistemin en sık görülen hastalıklarıdır. Hastaların yaklaşık \%30-71'i hayatının herhangi bir döneminde bir dermatolojik bulgu sergilemekte ve zaman zaman hekime başvurmaktadır (1). Araştırmamızda her iki grupta sık görülen deri bulguları olan fibroma molle, hemangioma, lentigo solaris ve seboreik keratoz, normal populasyonda da sık görülmekte ve yaş ile sıklığı artmaktadır. DM grubunda yaş ortalaması TH grubuna oranla daha yüksek olduğu için bu bulguları diyabet grubunda daha fazla saptadığımızı düşünmekteyiz.

Tablo I. Hastaların demografik özellikleri

\begin{tabular}{|c|c|c|}
\hline Özellikler & Diabetes Mellitus Grubu, n (\%) & Tiroid Hastalığı Grubu, n (\%) \\
\hline \multicolumn{3}{|l|}{ Cinsiyet } \\
\hline K & $56(56)$ & $89(89)$ \\
\hline $\mathrm{E}$ & $44(44)$ & $11(11)$ \\
\hline \multicolumn{3}{|l|}{ Yaş (yıl) } \\
\hline Min-maks & $33-89$ & $20-80$ \\
\hline Ortalama \pm ss & $59,5 \pm 10,36$ & $49,09 \pm 13,54$ \\
\hline \multicolumn{3}{|l|}{ Hastalık süresi (yıl) } \\
\hline Min-maks & $1-30$ & $0-60$ \\
\hline Ortalama \pm ss & $7,52 \pm 6,61$ & $7,77 \pm 10,35$ \\
\hline Ek hastalık öyküsü & $87(87)$ & $65(65)$ \\
\hline \multirow[t]{6}{*}{ Hastalık ölçütleri } & HbA1c (\%) & Tiroid fonksiyon testleri \\
\hline & Min-maks: 4,83-14 & \\
\hline & Ortalama \pm ss: $7,27 \pm 1,72$ & Ötiroidi: 49 (49) \\
\hline & HbA1c <7,2 (iyi): 64 (64) & Hipotiroidi: 35 (35) \\
\hline & 7,2>HbA1c $\leq 9$ (orta): 22 (22) & Hipertiroidi: 16 (16) \\
\hline & HbA1c>9 (kötü): 14 (14) & \\
\hline
\end{tabular}


Tablo II. Diabetes Mellitus grubunda gözlenen dermatolojik bulgular

\begin{tabular}{ll}
\hline Bulgular & $\mathbf{n}(\%)$ \\
\hline Fibroma molle & $51(51)$ \\
Onikomikoz & $38(38)$ \\
Hemangioma & $33(33)$ \\
Kserozis & $32(32)$ \\
Plantar hiperkeratoz & $32(32)$ \\
Lentigo solaris & $29(29)$ \\
Pruritus & $22(22)$ \\
Seboreik keratoz & $21(21)$ \\
Tirnak bulgusu & $20(20)$ \\
Tinea pedis & $20(20)$ \\
Rubeosis fasiei & $19(19)$ \\
Diyabetik dermopati & $17(17)$ \\
Eritrazma & $16(16)$ \\
Saç dökülmesi & $16(16)$ \\
Saç yağlanması & $15(15)$ \\
İntertrigo & $13(13)$ \\
Palmar eritem & $12(12)$ \\
Seboreik ekzema & $12(12)$ \\
Folikülit & $12(12)$ \\
Hiperhidroz & $10(10)$ \\
Pigmante purpurik dermatoz & $9(9)$ \\
İiyopatik guttat hipomelanozis & $9(9)$ \\
Gingival inflamasyon & $8(8)$ \\
Kandidiyazis & $7(7)$ \\
Kallus & $6(6)$ \\
Saç kuruluğu & $5(5)$ \\
Prurigo & $4(4)$ \\
Akantozis nigrikans & $4(4)$ \\
Liken simpleks kronikus & $4(4)$ \\
Saç incelmesi & $4(4)$ \\
Saç kalınlaşması & $1(1)$ \\
Psoriyazis & $4(4)$ \\
Diyabetik ayak ülseri & $3(3)$ \\
Oral aft & $3(3)$ \\
Fronkül & $3(3)$ \\
Tinea kruris & $3(3)$ \\
Aktinik keratoz & $3(3)$ \\
Verruka vulgaris & $2(2)$ \\
Vitiligo & $2(2)$ \\
Morfea & $1(1)$ \\
Pitriyazis versikolor & $1(1)$ \\
\hline & \\
\hline
\end{tabular}

Tiroid hastalıklarında tırnaklarda değişiklikler ortaya çıkabilmektedir. Hipotiroidizmde hastaların çoğunda kuru, kaba ve mat tırnaklar görülmekte iken, hipertiroi-
Tablo III. Tiroid hastalığı grubunda gözlenen dermatolojik bulgular

\begin{tabular}{ll}
\hline Bulgular & $\mathbf{n}(\%)$ \\
\hline Tirnak bulgusu & $64(64)$ \\
Saç dökülmesi & $45(45)$ \\
Kserozis & $37(37)$ \\
Plantar hiperkeratoz & $37(37)$ \\
Fibroma molle & $29(29)$ \\
Lentigo solaris & $26(26)$ \\
Hemangioma & $24(24)$ \\
Saç yağlanması & $23(23)$ \\
Saç kuruluğu & $22(22)$ \\
Onikomikoz & $17(17)$ \\
Seboreik ekzema & $16(16)$ \\
Seboreik keratoz & $15(15)$ \\
Saç kalınlaşması & $15(15)$ \\
Pruritus & $14(14)$ \\
İdiyopatik guttat hipomelanozis & $13(13)$ \\
Hiperhidroz & $12(12)$ \\
Eritrazma & $8(8)$ \\
Hipertrikoz & $7(7)$ \\
Palmar eritem & $7(7)$ \\
İntertrigo & $7(7)$ \\
Vitiligo & $6(6)$ \\
Tinea pedis & $6(6)$ \\
Folikülit & $6(6)$ \\
Pigmante purpurik dermatoz & $5(5)$ \\
Saç incelmesi & $5(5)$ \\
Urtikarya & $4(4)$ \\
Kallus & $4(4)$ \\
Kandidiyazis & $4(4)$ \\
Verruka vulgaris & $3(3)$ \\
Akantozis nigrikans & $3(3)$ \\
Sarı deri & $3(3)$ \\
Oral aft & $3(3)$ \\
Psoriyazis & $2(2)$ \\
Aktinik keratoz & $2(2)$ \\
Behçet Hastalığ1 & $1(1)$ \\
Liken planus & $1(1)$ \\
Prurigo & $1(1)$ \\
Morfea & $1(1)$ \\
Pitriyazis versikolor & $1(1)$ \\
\hline &
\end{tabular}

dizmde tırnaklar yumuşaktır ve kolay kırılır (5-8). Yaklaşık \%5 hipertiroidi hastasında sarı tırnak sendromu ve "plummer" tırnağı şeklinde tırnak bulgusu gözlenir. Sarı 
tırnak sendromunda; tırnaklar sarı renk alır, yavaş uzar, lunula ve kutikula kaybolur. Plummer tırnakları ise distal onikoliz ve 4 veya 5 . tırnaklardan başlayan tırnak konkavitesi ile karakterizedir (5). Araştırmamızda longitudinal çizgilenmeler, sarı-gri diskromi, distal onikoliz, tırnaklarda matlaşma ve tırnak plağında incelme gibi tırnak bulguları TH grubunda (\%64) DM grubuna oranla (\%20) daha yüksek oranda gözlenmiştir. Hasta grubumuzda sarı tırnak sendromuna rastlanmamakla birlikte \%1 hastada plummer tırnağı gözlenmiştir. DM grubunda tırnaklarda daha çok longitudinal çizgilenmeler, distal onikoliz, tırnakların matlaşması, konveksite ve konkavite artışı gözlenmiştir. Yapılan araştırmalarda diyabetik hastalarda normal populasyon ile kıyaslandığında tırnak yapısındaki proteinlerde moleküler değişiklikler saptandığı bildirilmiştir (9). Literatürde diyabetli hastalarda klinik olarak en çok gözlenen tırnak bulguları konkavite artışı, longitudinal çizgilenmeler ve distrofi olarak tanımlanmıştır (10). Tırnak üst yüzeyinde konveksite artışı ile karakterize koilonişya (kaşık tırnak deformitesi) uzun yıllardır diyabeti olan hastalarda gözlenebilmektedir. DM'de ayak tırnak distallerinde non-enzimatik glikolizasyonun veya karoteneminin yol açtığı düşünülen sarı tırnak da sıktır (11). Ancak araştırmamızda DM hasta grubumuzda kaşık tırnak deformitesi veya sarı tırnak sendromuna rastlanmamıştır. Bu bulguların gözlenmesi için daha geniş araştırma grupları üzerinde incelemeler yapılması gerektiğini düşünmekteyiz.

Diyabet hastalarının infeksiyonlara yatkınlığının artmış olduğu geçmişte çeşitli araştırmalarda gösterilmiştir. Kötü glikoz kontrolü sıklıkla deri infeksiyonları ile birliktelik göstermektedir. 2006'da Wang ve Margolis DM'li hastalardaki deri bulgularıyla ilgili bir araştırma yapmış ve kontrol grubu olarak hipertansiyon ve reflü gastritli iki grup hasta ile karşılaştırmıştır (12). Araştırma sonunda DM'li hastaların infeksiyonlara daha yatkın oldukları belirlenmiştir $(2,4,11)$. Romano ve ark DM'li hastaların $\% 20,6$ 'sında deri infeksiyonu gözlediklerini, bu infeksiyonların \%46'sının dermatofitler, \%35'inin kandidalar, $\% 12$ 'sinin bakteriler ve $\% 7^{\prime}$ sinin herpes simpleks virüs infeksiyonları tarafından oluşturulduğunu ve kötü metabolik kontrol ile istatistiksel anlamlı ilişki bulunduğunu belirtmişlerdir (13). İnfeksiyonlara olan yatkınlığın, azal- mış mikrosirkulasyon, hipohidroz, periferik vasküler hastalıklar, periferik nöropati, azalmış kemotaksis ve fagositoz yeteneğine bağlı olabileceği düşünülmektedir (2). Bu fonksiyon bozukluklarının, insüline bağlı hareket eden sitokinlerin eksikliği sebebiyle ortaya çıtı̆̆ı düşünülmektedir (4). Ayrıca DM'li hastalarda kan şekeri ile birlikte deri ve ter glikozunda da artma olduğu, derinin normal florası ve bu florayı normal tutan faktörlerin değişerek pek çok deri infeksiyonuna yatkınlık yarattığı belirtilmiştir (14). En sık görülen bakteriyel infeksiyonlar; Stafilokokus Aureus, beta-hemolitik streptokoklar ve Pseudomonas Aeruginosa'ya bağlı gelişen impetigo, follikülit, frunkülozis, karbonkül, ektima, selülit ve erizipel tablolarıdır. Corynebacterium Minutissimum infeksiyonuna bağlı eritrazma sıklığı da DM'lilerde artmıştır $(2,11)$. Nekrotizan fasiitis, rinoserebral mukormikoz ve malign eksternal otit ise nadir ancak diyabetik populasyonda sıklığı artan ve lethal olabilen infeksiyonlardandır (2). Tiroid hastalıklarında hormon düzeyi düşüklüğünün bakteriyel ve viral infeksiyonlara olan yatkınlığı artırdığına dair bir bilgi olmamakla birlikte, hipotiroidik sepsisli hastalarda sepsisin hiperdinamik fazının baskılandığı ve sepsis mortalitesinin arttı̆̆ını tanımlayan yayınlar bulunmaktadır (15). Bizim araştırmamızda, DM grubunda TH grubuna göre daha yüksek oranda folikülit, fronkül ve eritrazma saptanmış ancak aradaki fark istatistiksel olarak anlamlı bulunmamıştır.

Mikotik infeksiyonlar çoğu zaman diyabet hastalarında semptom oluşturmadığı için ihmal edilmekte ancak deri bütünlüğünü bozarak ikincil bakteriyel infeksiyonlara zemin hazırlamaktadır (11). Oluşan bu tablo ayak ülseri ve gangren gelişme olasılığını üç kat artırmakta ve nontravmatik alt ekstremite amputasyonlarının \%50-80'inden sorumlu tutulmaktadır $(16,17)$. Ülkemizde yapılan araştırmalarda, diyabetik hastalarda yüzeyel dermatofit infeksiyonlarının insidansının artmış olduğu bildirilmiştir. Şaşmaz ve ark yaptığı çalışmada deri infeksiyonları $(\% 31,7)$ oran ile en sık deri bulgusu olarak saptanmış ve bu infeksiyonları \%24,5 oranında mikotik infeksiyonlar, $\% 4,6$ oranında bakteriyel infeksiyonlar ve \%3,9 oranında viral infeksiyonların oluşturduğu belirlenmiştir (18). Gençoğlan ve ark yaptığı çalışmada \%60,6, Çiçek ve ark yaptığı çalışmada ise $\% 43,4$ oran ile dermatofitoz en sık 
gözlenen deri bulgusu olarak bildirilmiştir $(3,19)$. Bizim araştırmamızda da literatüre benzer şekilde DM grubunda en sık gözlenen deri infeksiyonu \%38 oranında onikomikoz olarak belirlenmiştir. Diyabetik ülser gelişiminin etyopatogenezinde suçlanan diğer faktörler ise iskemi, periferik nöropati ve kronik mikrotravmalardır (4). Bizim araştırmamızda DM grubunda diyabetik ülser gözlenme sıklığı \%3 olarak belirlenmiştir. Tiroid hastalıklarının da bazı mikotik infeksiyonlara olan yatkınlığı artırdığına dair literatür bilgileri bulunmaktadır. 2005 yılında Macura ve ark yaptıkları bir çalışmada ayak tırnağında Candida Albicans ve Trichophyton mentagrophytes'e bağlı onikomikoz oranı, tiroid hastalarında kontrol grubuna oranla daha yüksek bulunmuştur (20). Literatürde kronik mukokutan kandidiyazis, kandidal folikülit ve kandidal granulom ile hipotiroidizmin birlikteliğini bildiren olgu bildirileri bulunmaktadır (21-23). Bizim araştırmamızda da TH grubunda en sık gözlenen deri infeksiyonu \%17 oranında onikomikoz olarak belirlenmiştir. Tinea pedis oranı ise DM (\%20) grubunda TH (\%6) grubuna oranla daha yüksek saptanmıştır.

Tiroid hormonlarının doğal fonksiyonları destekleyici rolü nedeniyle, tiroid fonksiyon bozukluklarında en erken belirtiler genellikle deride gözlenmektedir. Hipotiroidinin karakteristik deri bulguları; genellikle ekstremitelerin ekstansör yüzlerinde soğuk, soluk ve kserotik deridir $(5,24)$. Kserozisin santral hipotermi, periferik vazokonstruksüyon, azalmış epidermal sterol biyosentezi, azalmış sebase gland sekresyonu ve hipohidrozun kombine etkisiyle oluştuğu düşünülmektedir. Araştırmamızda hipotiroidik hastalarda kserozisin anlamlı düzeyde yüksek olduğı saptanmıştır. Diyabette ise kserozis, dejeneratif komplikasyonlardan nöropatinin göstergesi olarak kabul edilmektedir. Bizim araştırmamızda da nöropatisi olan diyabet hastalarında kserozis istatistiksel olarak anlaml düzeyde yüksek saptanmıştır $(p=0,001)$. Yapılan araştırmalarda Tip 2 DM'li olgularda kserozis sıklığını Saray ve ark \%42,5, Gençoğlan ve ark \%53,92, Çiçek ve ark ise $\% 40$ olarak belirlemiştir. Bizim araştırmamızda da daha önceki literatür bilgilerine benzer şekilde kserozis sıklığı TH grubunda \%37, DM grubunda \%32 olarak belirlenmiştir.

Diyabetin kronik dejeneratif komplikasyonlarıyla ilişkili deri belirtileri arasında diyabetik dermopati, diyabetik kalın deri (skleredema diabetikorum), bulloz lezyonlar ve eritematoz belirtiler yer almaktadır. Diyabetik dermopati; tibial alanlarda 1-2 mm'lik atrofik hiperpigmante makulalar şeklinde görülmekte olup hastaların \%40'1nda saptanmaktadır (4,11). Araştırmamızda DM grubunda diyabetik dermopati oranı \%17 olarak belirlenmiş ve diyabet süresi arttıkça diyabetik dermopati insidansının anlamlı düzeyde arttı̆̆ı belirlenmiştir. Diyabetik hastalarda glikolizasyon ile kollagenin çözünürlüğü azalmakta, anormal çapraz bağlar oluşmakta ve immünojenitesi artmaktadır. Ayrıca yaş ile birlikte deride kollagen miktarında da azalma olması nedeniyle teorik olarak diyabet süresi arttıkça diyabetik dermopati sıklığının da artması beklenmektedir (11). Diyabetik kalın deri olarak tanımlanan antite; sert papulalar, eklem yastıkçıkları, eklem hareketlerinde kısıtlanma ve skleredema şeklinde görülmektedir (2). Diyabetik bullalar; ayak plantar ve yan yüzlerde ani başlayan, 0,5-3 cm çaplarda, gergin, ağrısız, seroz bullalardır. Her ne kadar diyabetin başlangıç bulgusu olarak düşünülseler de çoğunlukla uzun yıllardır diyabeti olan hastalarda gözlenmektedir (2). Araştırmamızda DM grubunda diyabetik kalın deri ve diyabetik bulla saptanmamıştır. Uzun süreli diyabette rubeozis fasiei adı verilen yüzde kızarıklık ve palmoplantar alanlarda eritem ortaya çıkmaktadır (4). Bu bulguların daha çok mikroangiopati ve nöropati zemininde oluştuğu düşünülmektedir (11). Bizim araştırmamızda da DM grubunda \%19 oranında rubeozis fasiei ve \%12 oranında palmar eritem saptanmış olup bu iki bulgu nöropati ile ilişkilendirilmiştir $(p=0,05$, $p=0,005)$.

Tiroid hastalarında artmış karoten metabolizması ile karotenin stratum korneumda depolanmasına bağlı palmar, plantar alanlarda ve nazolabial kıvrımlarda sarı deri tablosu ortaya çıkabilmektedir (5). Araştırmamızda TH grubunda \%3 olguda bu bulguya rastlanmıştır. Diğer deri bulgularından periorbital ödem, genişlemiş burun, şiş dudaklar, makroglossi, ifadesiz, donuk ve kaba yüz hipotiroidi için patognomonik bulgulardandır. Üst palpebral kasın azalmış sempatik situmulasyonu ile pitozis görülebilmektedir (5). Saçlı deri ve vücut kılları kuru, kaba ve kırılgandır ve hastalarının \%50'sinde difüz veya pariyetal alopesi gözlenmektedir. Kaşların lateral 1/3'lük kısmında dökülme hipotiroidi için tipik bir bulgudur (5). 
Hipertiroidik hastalarda ise deri 1lık, nemli ve yumuşaktır (25). Derideki sıcaklık; artmış kutanoz kan akımı, artmış sebase gland sekresyonu ve periferik vazodilatasyona bağlanmaktadır. Deri nemliliği özellikle palmar-plantar alanlarda daha belirgindir (5). Saçlar tipik olarak ince, kırılgan, yumuşak ve düz olmaya eğilimlidir. Bazı hastalarda difüz non sikatrisyel alopesi gözlenebilmektedir (25). Gravesli hastalarda ve akrabalarında saçlarda erken ağarma görülebilir (26). Bizim araştırmamızda da saç bulguları TH grubunda DM grubuna oranla anlamlı derecede daha fazla saptanmıştır. Hipotiroidi hastalarında saç dökülmesi, saçlarda kuruluk, kalınlaşma ve matlaşma, hipertiroidi hastalarında ise saç dökülmesi ve saç yağlanması ağırlıklı bulgular olarak belirlenmiştir. Genel populasyonda saç dökülmesinin bir çok nedeni olabilmekle birlikte, bu yakınmalar ile başvuran hastalarda tiroid hastalıkları yönünden de araştırma yapılması gerektiğini düşünmekteyiz $(6,27,28)$.

Sonuç olarak yaptığımız araştırmada hem DM hem TH grubunda pek çok dermatolojik bulgu gözlenmiştir. Bu bulguların çoğu genel toplumda da sık gözlenen ve bu hastalıklara özgün olmayan bulgulardır. Ancak özellikle ileri yaş grubundaki diyabetli hastalarda önemli morbidite ve mortalite nedeni olan, diyabetik ayak gibi komplikasyonlara yol açan mikotik infeksiyonlar bizim araştırmamızda da yüksek oranlarda saptanmıştır. DM hastalarında mikotik infeksiyonlar deri muayenesinin rutin bir parçası olarak araştırılmalı, mevcut infeksiyonlar için gerekli tedaviler uygulanmalı ve hastalar koruyucu önlemler açısından bilgilendirilmelidir. Birtakım deri bulgularının DM'nin vasküler komplikasyonlarına işaret etme olasılığı bulunması nedeniyle, hastalar bu açıdan izlenmeli ve gerekli multidisipliner yaklaşımlar açısından yönlendirilmelidir. Bunun yanında saç dökülmesi, saç yapısında değişiklikler ve tırnak bulguları ile dermatoloji polikliniklerine başvuran olguların klinik ve laboratuvar incelemeler ile tiroid hastalıkları açısından araştırılması uygun olacaktır. Toplumda sık oranda gözlenen ve geniş bir yelpazede dermatolojik bulgular sergileyen bu endokrinolojik hastalıklarda kontrol gruplarını da içeren daha geniş seriler ile yapılacak prospektif araştırmalara ihtiyaç vardır.

\section{KAYNAKLAR}

1. Al-Mutairi N, Zaki A, Sharma AK, Al-Sheltawi M.
Cutaneous manifestations of diabetes mellitus. Study from Farwaniya hospital, Kuwait. Med Princ Pract 2006;15:427-430.

2. Ahmed I, Goldstein B. Diabetes mellitus. Clin Dermatol 2006;24:237-246.

3. Şensoy N, Gençoğlan G. Tip II Diyabetli Hastalarda Deri Bulgularının Vücut Kitle İndeksi Ve Hbalc İle İlişkisi. Anatol J Clin Investig 2009;3:213-217.

4. İşçimen A, Arzuhal N. Diabetes Mellitus'lu Hastalarda Görülen Deri Belirtileri. Dermatose 2004;3:18-25.

5. Doshi DN, Blyumin ML, Kimball AB. Cutaneous manifestations of thyroid disease. Clin Dermatol 2008;26:283287.

6. Heymann WR. Cutaneous manifestations of thyroid disease. J Am Acad Dermatol 1992;26:885-902.

7. Mullin GE, Eastern JS. Cutaneous consequences of accelerated thyroid function. Cutis $1986 ; 37: 109-114$.

8. Robson KJ, Piette WW. Cutaneous manifestations of systemic diseases. Med Clin North Am 1998;82:13591379.

9. Farhan KM, Sastry TP, Mandal AB. Comparative study on secondary structural changes in diabetic and nondiabetic human finger nail specimen by using FTIR spectra. Clin Chim Acta 2011;412:386-389.

10. El Darouti MA, Hussein S, Al Tahlawy SR, et al. Clinical study of nail changes in leprosy and comparison with nail changes in diabetic patients. J Eur Acad Dermatol Venereol $2011 ; 25: 290-295$.

11. Bristow I. Non-ulcerative skin pathologies of the diabetic foot. Diabetes Metab Res Rev 2008;24:84-89.

12. Wang YR, Margolis D. The prevalence of diagnosed cutaneous manifestations during ambulatory diabetes visits in the United States, 1998-2002. Dermatology 2006;212:229-234.

13. Romano G, Moretti G, Di Benedetto A, et al. Skin lesions in diabetes mellitus: prevalence and clinical correlations. Diabetes Res Clin Pract 1998;39:101-106.

14. Savin JA. Bacterial infections in diabetes mellitus. Br J Dermatol 1974;91:481-484.

15. Moley JF, Ohkawa M, Chaudry IH, et al. Hypothyroidism abolishes the hyperdynamic phase and increases susceptibility to sepsis. J Surg Res 1984;36:265-273.

16. Winston JA, Miller Jl. Treatment Of Onychomycosis İn Diabetic Patients. Clinical Diabetes 2006;24:160-166. 
17. Rich P, Hare A. Onychomycosis İn A Special Patient Population: Focus On The Diabetic. International Journal Of Dermatology 1999;38:17-19.

18. Şaşmaz S, Büyükbese MA, Çetinkaya A, Çelik M, Özer A. The Prevalence of skin Disorders İn Type 2 diabetic patients. The İnternat Journal of Dermatol 2005;3;1.

19. Ciçek D, Kandi B, Oğuz S ve ark. Diabetes Mellituslu Hastalarda Gözlenen Deri Bulguları. Fırat Üniversitesi Sağlık Bilimleri Tıp Dergisi 2010;24:77-80.

20. Macura AB, Gasińska T, Pawlik B. Nail susceptibility to fungal infections in patients with hypothyroidism and hyperthyroidism. Przegl Lek 2005;62:218-221.

21. Myhre AG, Stray-Pedersen A, Spangen S, et al. Chronic mucocutaneous candidiasis and primary hypothyroidism in two families. Eur J Pediatr 2004;163:604-611.

22. Dekio S, Imaoka C, Jidoi J. Candida folliculitis associated with hypothyroidism. Br J Dermatol 1987;117: 663-664.

23. Papazian CE, Koch R. Monilial granuloma with hypothyroidism: report of a case treated with amphotericin B. N Engl J Med 1960;262:16-18.

24. Freinkel R. Cutaneous Manifestations Of Endocrine Diseases. Dermatology İn General Medicine. Ed. Fitzpatrick TB. Eizen A, Wolff K, Freedberg I, Austen K. Fourth Edition. New York: Mc-Graw-Hill Book Company, 1993; 2:2113-2129.

25. Janie M. Leonhardt, Heymann Wr. Thyroid Disease And The Skin. Dermatol Clin 2002;20:473-481.

26. Mullin G, Eastern J. Cutaneous Consequences Of Accelerated Thyroid Function. Cutis 1986;37:109-114.

27. Elgart GW, Patterson JW, Taylor R. Cutaneous metastasis from papillary carcinoma of the thyroid gland. $J$ Am Acad Dermatol 1991;25; 404-408.

28. Koller EA, Tourtelot JB, Pak HS, Cobb MW, Moad JC, Flynn EA. Papillary and Follicular Thyroid Carcinoma Metastatic to The Skin: A Case Report and Review of the Literature Thyroid 1998;8:1045-1050. 